ASARC Working Paper 2013/03

\title{
The role of bribes in rural governance: The case of India
}

Hari Nagarajan, Raghbendra Jha, and Kailash C. Pradhan ${ }^{1}$

\begin{abstract}
Given that the phenomenon of capture of public programs by sections the population is rampant in developing countries, households can indulge in a strategy to improve their participating in public programs by bribing the suppliers of such programs. This is an important issue affecting both the supply of local public goods and the incidence of corruption. To the best of our knowledge there is no analysis of the impact of bribery on participating in a local public goods program, anywhere. Using a unique data set for rural India this paper addresses the question of whether households bribe elected officials responsible for assuring such supply to improve their access to local public goods. We find considerable evidence of such bribing. We also model the welfare effects of such bribing on groups of households as well as the impact of bribery on aggregate welfare. Several policy conclusions are advanced.
\end{abstract}

JEL Classification Codes: D31, D63, D73, O12

Keywords: Bribery, Program Capture, Welfare Effects, Rural India.

\footnotetext{
${ }^{1}$ Hari Nagarajan and Kailash Pradhan are Senior Fellow and Associate Fellow respectively of the National Council of Applied Economic Research, New Delhi, India, while Raghbendra Jha is Professor of Economics at the College of Asia \& the Pacific, The Australian National University.
} 


\section{Introduction}

It is well known that Indian villages are very deficient in the supply of local public goods, although some improvements have been made over time. Using Census data for 1991 and 2001 Table A1 shows large deficiencies in villages in respect of several key public goods, e.g., in 2001 only 41 per cent of villages had access to tap water. Although other sources of water were available there may be several instances of overlap, e.g., villages with access to water from a river may also have tap water. Further, the incidence of such deprivation may fall very unevenly within households. Thus, Desai et. al. (2011) show that, on average, rural women spend 66 minutes day fetching water, whereas men spend 29 minutes.

It is against this background that the Panchayati Raj Amendment to the Indian Constitution sought to delegate more administrative and financial powers to village panchayats (councils). A long and distinguished tradition in public economics (for a review in the context of developing countries see Banerjee et.al. 2007) has consistently argued that decentralization of provision of public goods leads to better matches of public goods to pubic tastes and is therefore preferred. Further, democratic functioning of local administration is considered to lead to greater accountability which would reduce the scope for corruption (Banerjee et. al. 2007).

This paper deals with the issue of whether such devolution of responsibilities and, consequently, the subsequent enhancement of welfare have been compromised by rising corruption. Using a unique dataset (REDS 1999 and 2006) we find that the payment of bribes by households increased by almost 40 percent between the 1999 and the 2006 round of the REDS. Bribes are being paid to have problems resolved associated with public services, to improve services to the household or get access to programs, and to offset expected malpractices. Some bribes are paid directly to elected officials, but most bribes are paid to people who have connections to those who manage programs, be they Panchayat elected officials or staff, higher level Panchayat officers, or civil servants of the sectors that are involved in service delivery, and development and welfare programs.

People would not pay bribes if they were able to have their problems resolved and gain access to welfare program without doing so in a local government system that was transparent, with efficient service providers, and with elected and appointed officials of the local government and the services being both approachable and accountable to the citizens. 
The bribes therefore are a symptom that the entire rural governance system, not just the Panchayati Raj Institutions (PRI), is not transparent and not efficient, and that neither politicians nor service providers can be easily approached and held properly to account by the citizens. That they are increasing means that these problems are getting worse, rather than better.

Bribes could be increasing because the governance system is deteriorating further, or because the programs for whose benefits bribes are being paid are increasing. Centrally sponsored schemes and Panchayat public expenditures on welfare programs have increased sharply. Clearly, therefore, the growing opportunities for paying bribes are one of the reasons for their growth.

In this paper we first pursue the question of what determines the payment of bribes. In particular we ask whether the level and the prevalence of bribes could be reduced via governance reforms. a) Would it help to shift the process of beneficiary selection and administration of developmental expenditures to sector staff instead or, to a non- elected but a representative body such as the Gram Sabha? b) Would greater attendance at Gram Sabha meetings reduce payments of bribes? And c) Would it helps to have more female elected officials, in particular more female Pradhans. The answer to the first question is mixed, while the answer to the second two questions is positive.

Bribes can affect the delivery of public goods, access to services such as health and water supply, offset malpractices, and provides access to welfare programs. It is this fourth impact which we measure in this paper, and show to be quite large, especially for people below the poverty line.

Finally we explore the impact of payment of bribes on household consumption. This impact could occur via all of the four impacts of bribes discussed in the last paragraph, but especially from gains in income associated with access to welfare programs. Again we show that the payment of bribes can have a large impact on consumption, with the proportional impact being especially large for the ultra-poor, followed by the poor. Both of these income strata would have experienced a decline in consumption had they not paid bribes, which suggests that they have no choice, but paying bribes.

We interpret the payment of bribes as a second-best response by citizens to the serious deficiencies of local governance in terms of transparency, efficiency, and accountability. 
Under these circumstances they need to induce the elected and appointed officials to do their job properly or give them access to welfare payments by paying a bribe. This leads to private benefits of both the bribe payer, and of the person receiving the bribes. But as with all second-best solutions, it is not clear that, given the deficiencies in the governance system, whether the bribes lead to an overall increase in social welfare. Additional research will be required to sort this out.

The plan of the paper is as follows. We first discuss the data and provide a descriptive analysis. We then discuss our methodologies, followed by a results section. We close with conclusions and policy implications.

\section{Data and descriptive analysis}

We use data from the Rural Economic and Demographic Survey (REDS) conducted by the National Council for Applied Economic Research (NCAER).These surveys were started in 1969 and represent a panel of 241 villages representing 17 major states of India. In addition to information included in standard multi-purpose household surveys, the REDS contain data on bribes at the household level. We have disaggregated data on the functionary approached (elected or otherwise) by the household for solving a range of problems germane to both community and the household, number of functionaries approached, frequency of such visits, and the specific bribe paid and its frequency. We also have at the member level the incidence of bribes associated with specific services such as health, receipt of welfare benefits, and beneficiary selection.

The survey is in three parts. The listing questionnaire is a census of all the villages covered and provides detailed information of the primary and secondary occupation of the household head, net income, migration, social and economic networks, whether social discrimination was experienced, voting in elections, and Jati. The village questionnaire provides us with details of all aspects of governance including elections, Gram Sabha meetings, government programs, taxation, expenditures, number of village level shocks, amongst other variables. The household and member level information related to voting and program participation is derived from the household survey. The size of the sample in 1999 and 2006 surveys is 7474 
and 8659 households respectively, of which 5885 households were interviewed in both rounds. These two survey rounds cover two Panchayat periods. ${ }^{2}$

In this section we briefly describe the relevant portions of this data and provide an assessment of quality of governance and the resulting pathologies like bribes in the Panchayats. Table 1 provides details on the sample size, village, and household characteristics. The average number of households in these villages was 700 in 2006, up by $12.46 \%$ since the previous survey. Foster and Rosenzweig (2004) citing the 2001 census suggest that the REDS villages are larger in terms of household population compared to an average village in India.

\section{Table 1 here}

Household sizes shrunk by nearly $16 \%$ and the average age of the household head increased over the same period by 3.5 years. The household heads were better educated in 2006 than in 1999 (though only marginally so) and the proportion of girl children attending schools in 2006 was higher by 30\%. The changes in poverty rates are worth exploring. While overall poverty declined by $18.3 \%$, the magnitude of the ultra poor registered a significant increase (though representing only 3\% of all households in these villages). The proportion of poor declined by $25.8 \%$ while that of the affluent registered an increase of $22 \%$ (the magnitude of non poor went up by 3\%). Hence, village welfare as represented by the poverty head count improved. There was approximately 1 adverse village wide shock per year in each of the Panchayat periods and the number of household level shocks experienced by households was about the same. Inherited wealth (including land) went up by $26.71 \%$. This could be attributed to the strengthening of inheritance laws during this period (Deininger et al 2012c).

Per capita Panchayat expenditures on various schemes and public goods changed. Consistent with the policies of the central government, growth in per capita welfare expenditures (tied resources) grew by the most (by 77.5\% and in 2006 the average number of centrally sponsored schemes per village stood at 14-a growth of nearly 15\% over two Panchayat periods). Untied funds transferred to the Panchayats and spent also grew - by $30.36 \%$. Of significant concern is the magnitude of change in expenditures on public goods and on directly productive activities like agriculture. While public goods expenditures grew by a

\footnotetext{
${ }^{2}$ One Panchayat period is approximately 5 years and starts with the election of the Pradhan. Since the household survey was completed in 2008 we are able to cover two Panchayat periods in 230 out the 241villages. A Panchayat is an administrative unit and encompasses two or more villages. These villages act as wards-a lesser administrative unit.
} 
mere $0.48 \%$ the magnitude of expenditures on agricultural programs declined by $48.6 \%$. This implies that households had access to significantly larger financial resources in 2006 than were previously unavailable-and not necessarily related to or derived from productive activity. Such growth in tied (program) expenditures can lead to certain pathologies. If selection and participation in welfare programs is constrained because of the fact that these are administered in a silo based manner from which the local bureaucracy derives the power to discriminate then, households would have to resort to payment of bribes to access these resources.

There were gender based regime changes in Panchayats as a result of elections (this applies to only those Panchayats that are not reserved for women under the $73^{\text {rd }}$ Amendment-33\% reservations is mandated and the Panchayats are randomly selected). We find that in 2006 $26 \%$ of all villages elected a female Pradhan in place of a male and, $22 \%$ of unreserved villages had a male Pradhan in place of a female. Deininger et al (2012 a, b) have shown that the quality of governance in general, and in particular in matters such as beneficiary selection are better in such villages with women pradhans. One could therefore infer that regime changes that lead to the election of female Pradhan in place of a male Pradhan is reflective of the positive outcomes observed in the Panchayats that have been reserved for women.

For the purpose of this paper we posit that improved quality of governance should minimize the tendency of households to undertake second best solutions such as payment of bribes for outcomes such as being able to participate in welfare programs. There are other features with possibly adverse consequences in terms of program capture and accountability in the system, including a significant degree of political interference, and the presence of dynasties. In 2006 $19 \%$ of all Pradhans belonged to the same family (a growth of 43\% over 1999). Political support from parties in matters related to Panchayats was significant. 86\% of all Panchayats have Pradhans and ward members who have received support from political parties or were sponsored by these parties.

We find two interesting facets related to quality of governance that experienced a substantial increase. The number of Gram Sabha meetings increased by $46 \%$ and the attendance in such meetings increased by $16.6 \%$ from the previous panchayat period, and was quite high in 2006: $88.2 \%$ of all members in the village having attended at least 1 meeting.). It is worth exploring whether such increased rates of participation or increases in number of meetings could reduce the need to pay bribes. 
On average households paid Rs. 120 in bribes in 1999 which increased to Rs 167 in 2006, an increase of 39 percent. Why do households pay bribes? From the survey ${ }^{3}$ it clear that households are paying bribes to a) have problems that might affect public services in the community resolved, b) improve services to their own household and derive private benefits in terms of program access, and, c) offset expected malpractices. When beneficiary selection and program management are devolved to Panchayats, these would typically be the elected officials, the Panchayat secretary, or the Gram Sabha. In cases where these functions are not devolved, it would be personnel from sectors that administer the program, who often might be found at the block, rather than the village level. This means that the results in this paper deal with bribes as a consequence of pathologies in the entire rural governance system, including sectors, not only in the Panchayats and their elected representatives and staffs.

\section{Table 2 here}

From the top panel of Table 2 it is clear that bribes are being paid to ameliorate almost all of the problems associated with public services at the village level. For example $77.7 \%$ of all households in the village were adversely affected by poor quality of provision of drinking water and irrigation. Out of which $82 \%$ have paid bribes to both elected officials of the Panchayats and other connected with water administration at the village level to redress this problem at the village level. Two other factors stand out. First, even though the proportion of households adversely affected declined marginally, those that pay bribes have increased over the same period. Second, the number of functionaries that a household had to approach to have problems redressed before paying bribes to any one of them has increased. In 1999 this number ranged (for water) between 0 and 12 for an average household, widening in 2006 so that the maximum number of people that households in the villages had to approach for resolving water related problems was 18. Is this information asymmetry, or, is it poor implementation of the Panchayati raj reforms? Could it due one of lack of empowerment? We are not in a position to answer these questions here. Whatever be the cause, the data reveal a disturbing trend of significantly large portions of the village community being adversely affected by community wide poor quality services provision and having to pay bribes to improve the quality or resolve the problems. The increase in the average number of functionaries approached is also disquieting.

\footnotetext{
${ }^{3}$ Table 2 reports the statistic from the Panel of households. We in a way are able to examine the persistence of bribes when this information is taken along with table 4.
} 
We developed an index of the concentration of bribe payments in each village. For each recipient we measured the choice of bribes paid directly to elected officials (the Pradhan or the Ward members), relative to total bribes paid to individuals perceived to have connections to elected individuals and bribe paid to elected officials. The bribe concentration index therefore varies from zero, when all bribes are paid to related individuals, to one, when all bribes are paid to the elected officials directly. A low bribe concentration index points to the existence of a bribe network. Such networks could arise, for example, if the likelihood of the elected representatives being caught is large, and if such an event is likely to negatively affect their careers. A bribe network can be used to disguise the ultimate beneficiary of the bribes. On the other hand, a low bribe concentration index in a village could also reflect the relative inability of households to directly approach the elected representatives for access to benefits and problem solving. The index in 1999 is only 0.04 and rose to 0.07 in 2006, suggesting that most bribes are paid to network members rather than the principals. The growth in the index suggests that in 2006 a few more bribes were being paid directly to the elected representatives - but the magnitude (in rupee terms) of such direct bribe payments was still small.

The middle panel and the final part of the table reports the incidence of bribes associated with solving private problems, including bribing to improve the quality of services such as education and health, getting public works project done satisfactorily in the vicinity of the residence, and avoidance of malpractices. The number of households that are adversely affected by the quality of public works (such as flood prevention, piling of garbage, sewerage, roads etc) within the vicinity of their residence was high and growing and, 79.5\% of all affected households paid bribes to improve the conditions. Further, the average number of functionaries that the household approached in 2006 was over 2.

A question relevant for this paper directly is whether the affected households lived in specific streets, i.e., the incidence of bribes for improving public works in the vicinity of the residence is worth exploring. Munshi and Rosenzweig (2008) show that households that live in streets in which the elected representatives of the Panchayats reside are on an average better off than others in the village with respect to access to public services and services related to the public distribution system. This may meant that both the adversely affected and bribe paying households reported in Table 2 resided in streets where such representatives do not reside. But an answer to this question is outside the scope of this paper. 
Tables 3 and 4 taken together show the Panchayats in general and targeting and accessing welfare programs in particular in a rather poor light. Across consumption classes the number of functionaries to be approached for problem solving by households went up. This could reflect inadequate or incorrect devolution of powers. Households approached multiple functionaries for various reasons, possibly fragmentation of powers, or, information asymmetry in the system wherein the household was not aware of the correct functionary. Whatever the reason, the Panchayats as institutions do not come off well in Table 3. Further, more households pay bribes for accessing programs, problem resolution, improving the quality of services, and avoiding malpractices than before. The finding of concern is that while 29.8\% of poor households paid bribes in 1999 this figure rose to 33.7\% in 2006 .

\section{Tables 3 and 4 here}

From table 43 things come out. First, the average value of bribes paid per household in 2006 was Rs167.33, up from Rs. 120.33 during 1999. Second, 97\% of all bribes are paid to those with perceived links to elected members of Panchayats. Finally, a significant and growing proportion of households participated in welfare programs in both panchayat periods but had to pay bribes repeatedly to continue participation. The average number of bribe episodes per year is 8 during the 2006 Panchayat period translating to nearly 6\% of per capita consumption. If households are expected to pay bribes into the future then this could reduce the expected consumption growth and lead to increased vulnerability.

The fact that most bribes are being paid to functionaries with perceived links to elected officials is reflective of the following. a) Certain households were unable to approach the elected officials or were being discriminated against by such officials. Therefore they would rather make use of the network to which these officials belong to according to the households and try and get access to the services and benefits. This could imply a general lack of accessibility of the elected representatives for problem resolution. It would imply a poorly functioning local government. b) It could also imply that there is a genuine lack of information about the mechanisms of service provision and process of governance on the part of the households. Either way this statistic presents a system with widespread incidence of and increases in bribes.

Finally the statistic on repeated payment of bribes, even of those participating in programs over a period of time, suggests that there is a significant correlation between continued 
participation and payment of bribes. The fact that of all such households this figure was $32.03 \%$ in 2006 compared to $16.92 \%$ in 1999 suggests that repeated bribes contribute to private economic benefits of households.

Three policy questions can be addressed to Tables 2, 3, and 4. If the beneficiary selection or administration of various programs is done by elected or appointed officials of Panchayats, would it help to shift the selection process to sector staff instead? (Or, shift the selection to a non- elected but a representative body such as the Gram Sabha?) If selections are done by sector staff, would it help to elevate it to higher levels of the Panchayats which could help in enforcing and verifying rigorous criteria, and make participation more predictable? If the answer to either of these questions is yes, bribes should decrease otherwise bribes will continue unabated or even increase, only the identity of the recipient will change. The third question is whether, for given level of participation, it will help to make payments directly to the beneficiary. In this case bribes to ensure participation would continue, but the need to bribe to actually receive the benefits will either reduce or disappear.

The MGNREGS is designed such that Panchayats are deeply involved in the administration However, the MGNREGS now transfers benefits directly to the beneficiaries' bank accounts. The work of the Panchayat officials is to provide the beneficiary household with a job card and employment whenever asked (and the fact that MGNREGS funds have been released will be known during Gram Sabha meetings and the households participating in such meetings can therefore hold the Panchayat officials to account). Can such a design reduce the payments of bribes? Evidence from a survey done by one of the authors in all of the REDS villages of Uttar Pradesh, Maharashtra and Orissa shows the following; at the time of delivery of the job card, the Panchayat official comes to an "agreement" with the beneficiary wherein the beneficiary agrees to part with a potion of the transfers. This is how it works in some of the observed cases: The Job card is released to the applicant and 100 days work is granted at the rate of Rs 150 per day. Of the Rs 15000 transferred to the beneficiary, the aforementioned beneficiary "agrees” to "give” Rs 5000 to the official against 0 days of actual work. In Uttar Pradesh, 30\%, the percentage of all such "beneficiaries have paid such bribes." is $44 \%$. Therefore direct transfers and Panchayat administration may not reduce the payments of bribes and payments for no work provided. 


\section{Methodology}

We posit that changes in changes in bribes, consumption growth and program participation are jointly determined and endogenous to each other. Therefore, a three stage estimation strategy is adopted presuming the existence of a linear system of $\mathrm{M}$ equations with jointly dependent and predetermined variables.

$$
\begin{array}{lc}
y_{i}=Y_{i} \gamma_{i}+X_{i} \beta_{i}+u_{i} & i=1,2 \ldots \mathrm{M} . \\
y_{i}=Z_{i} \delta_{i}+u_{i}, & Z_{i}=\left(Y_{i} X_{i}\right)
\end{array}
$$

where the T-vector $y_{i}$ contains the observations on the ith dependent variable to be explained by the $i$ th structural equation; $Y_{i}\left(T \times m_{i}, m_{i}<M\right)$ less than or equal $M$ contains observations on jointly dependent variables included as explanatory variables in the ith equation, $X_{i}\left(T \times l_{i}, l_{i}<A\right)$ less than or equal $\mathrm{A}$ is the matrix of predetermined variables included in the ith equation, $\gamma_{i}$ and $\beta_{i}$ are corresponding vectors of unknown parameters, $u_{i}$ is a T-vector of disturbances satisfying

$$
\begin{aligned}
& E\left(u_{i}\right)=0, \\
& E\left(u_{i} u_{i}^{\prime}\right)=\sigma_{i j} I_{T}, \quad i, j=1,2 \ldots \mathrm{M} .
\end{aligned}
$$

The distribution of the disturbances is supposed to be independent of the predetermined variables in the system, the reduced form is assumed to exist and the equations are either just identified or over identified (Kapteyn and Fiebig, 1981).

\section{i) Estimating Payment of Bribes}

We construct a bribe index to measure the diversity of bribes. The bribe index (at the village level is:

$$
B I_{i}=\sum_{i}\left(\frac{A B_{i}}{T B_{i}}\right)
$$

where $B I_{i}$ is the bribe index of a given household $i$ and $A B_{i}$ is the amount of bribe paid to the Pradhan or Ward members and $T B_{i}$ is the total amount of bribe paid to functionaries who are perceived by the households to have links to the elected members of the Panchayats. The village bribes index ranges from 0 to 1 . If the value is 1 then all bribes are being paid only to the elected representatives. The way we wish to interpret the impact of this index is to see 
whether increased payment of bribes to the elected members by all other households of the village will increase bribe payment by any given household. The bribe index uniquely identifies the changes in payment of bribes which is estimated as follows:

$$
\Delta B_{i t}=\tau_{0}+\tau_{1} \Delta B I_{-i t}+\omega_{p} R C_{P t, P t-1}+\phi_{l} \sum_{l} C_{l i t}+\varepsilon_{i t}
$$

where, $\Delta B_{i t}$ is change in bribes paid, $\Delta B I_{-i t}$ is the change in bribes paid by all other households in the village, $R C_{\text {Pit,Pit-1 }}$ is the gender based regime change in the Panchayat (resulting from elections and not due to political reservations); $\sum_{l} C_{l i t}$ is the vector of other household and village level controls such as participation in gram sabha meetings, presence of a re elected Pradhan, and political support for the candidates during election and after.

We include three other identifiers that are exogenous to the Panchayats. These are related to devolution powers by the respective State Governments to the Panchayats. If Bribes are associated with inefficiencies of the system then it is important to know whether the Panchayats had autonomy over expenditures, execution of projects and, whether the responsibility of beneficiary selection was adequately devolved. If one argues that bribes are a result of both information asymmetry within the village between the elected representatives and the households, and such information asymmetries are the result of inadequate devolution then bribes must certainly diminish with increased devolution.

\section{ii) Estimating Changes in Per Capita Consumption}

Change in household's welfare is measured by changes in its change in per capita consumption. Change in per capita consumption is estimated as follows.

$$
\Delta C_{i t}=\alpha_{0}+\alpha_{1} \bar{W}_{i t}+\beta_{1} \Delta B_{i t}+\lambda_{k} \sum_{k} X_{k i t}+\mu_{i t}
$$

where, $\Delta P C_{i t}$ is the change of per capita consumption expenditure, $\bar{W}$ is the predicted wealth, $X_{i j t}$ is a vector of exogenous variables that includes the public expenditures on agricultural programs, public expenditures on welfare programs, village untied grants, village level shocks, household level shocks, age of the head of the household, household size, average education in household, and, $\mu_{i t}$ is the random error. 
The unique identifiers for the consumption function are predicted changes in household wealth. Change in wealth is a consequence of household splits and will adequately explain changes in per capita consumption at the household level. ${ }^{4}$

\section{iii) Estimating Participation in Welfare Programs}

Change in number of welfare programs participated in by the household is estimated as follows:.

$$
\Delta W P_{i t}=\pi_{0}+\varpi_{1} \Delta B_{i t}+\varpi_{2} \Delta W_{v t}+\gamma_{m} \sum_{m} M_{m i t}+\vartheta_{i t}
$$

where $\Delta W P_{i t}$ is change in the number of welfare programs participated by household $i, \Delta B_{i t}$ is change of bribe payment by the household, $\Delta W_{v t}$ is the change in the number of welfare programs in the village, $\sum_{m} M_{m i t}$ is vector of variables which includes, changes in payment of bribes interacted women's reservation in the Panchayat, poverty status, growth in agricultural programs, growth in public goods, and growth in general welfare programs. The unique identifier for this equation is change in number of welfare programs in the village.

What do bribes accomplish? We have seen in Tables 2, 3, and, 4, that bribes are being paid for a variety of reasons and to a range of recipients. In this paper, bribes provide improved or differential access to programs and, hence, lead to increases in economic welfare of households though increases in consumption. Bribes are also often paid to maximize both private and group benefits. The latter point is worth elaborating. If households derive benefits due to identification with a specific group-economic or social- then undertaking strategies to maximize group benefits might be source of insurance. Can bribes confer such benefits? We know that such benefits accrue to the group if the Marginal Odds of Participation (MOP) are greater than the Average Odds of Participation (AOP). The AOP is the ratio of the average number of programs participated in by a specific class of households and the overall average

\footnotetext{
${ }^{4}$ Here we estimate predicted change in household's wealth. Changes in household wealth are often a consequence of household splits. Predicted household splits adequately predict changes in wealth (Foster and Rosenzweig, 2001). We predict the change in wealth as follows.$$
\Delta W_{i t}=\kappa_{0}+\phi_{j} S_{j i t}+v_{i t}
$$

Where, $i$ indexes households, $j$ the variables and $t$ is time, $\Delta W_{i t}$ is the change in household's wealth, $s_{j i t}$ is the vector of variables that predict whether a household will split. It includes age of head of the household, change in variance and mean of education of members of household, number of children whose age is less than 15 years, inherited wealth at the beginning of the period (1999), dummies for whether father is co-resident at beginning and at end of the periods (1999 and 2006), dummies for whether both brothers and sisters are coresident at the beginning and end of the period (1999 and 2006) and, $v_{i t}$ is the error term.
} 
across all classes of households. The MOP is the increment to participation in a given program by a given class of households. If the MOP is greater than the AOP for any class of households for any given program then that program is being "captured” by the given consumption class. We can extend this argument within specific classes. If, for a given household, its MOP is greater than the AOP for the class in which it is a member of, then, this implies that the given household is increasing its chances of participation relative to all others within that group.

\section{iv) Program Capture}

In order to determine whether bribes lead to program capture, we estimate the following equation for different classes of households. For our purposes we identify households by their respective consumption class as ultra poor, poor, non poor, and, affluent. For a given household $\Sigma$ belonging to consumption class $p$ (poor) the average odds of participation (we assume for simplicity of analysis that all programs are homogeneous and there does not exist any preference ordering) is written as

$$
A P_{i t}^{p}=\varphi_{0}+\varphi_{1} \hat{T P}_{i t}+\varphi_{2} w_{i t}+v_{z} \sum_{z} R_{i t}+\psi_{i t}
$$

where, $A P_{i t}^{p}$ is the average number of programs participated in by a household that is poor, $\hat{T P}_{i t}$ is the predicted average village participation rate, $w_{i t}$ is the off farm wage rate, and, $R_{i t}$ is the vector of household level such as education, household size. Since $\hat{T P}_{i t}$ is endogenous, it is instrumented out in the following manner.

$$
T P_{i t}=f\left(T P_{-i t}^{-p}, W, \hat{B}_{i t}^{p}, \hat{\bar{B}}_{-i t}^{-p}\right)
$$

where, $\hat{T P}_{i t}$ is the predicted average village participation rate. The average total participation rate of all other groups is $\overline{T P}_{-i t}^{-p}, \hat{B}_{i t}^{p}$ is the predicted bribe paid by a poor household and $\hat{\bar{B}}_{-i t}^{-p}$ is the predicted average bribe paid by households in all other groups. The coefficient $\varphi_{1}$ is the MOP for that household (or for households for a given consumption class if we estimate these regressions at the aggregate level). If the MOP is greater than the AOP then, this implies capture by the household or, by the consumption class. 


\section{Results}

We estimated the system of equations shown in 1 and 2 and 3, with results shown in Table 5. The Chi2 values for all three equations are statistically significant, and the HansenSargan test indicates that the system is over-identified. In panel 5 a) the results for the bribe equation are shown, those for the participation equation are shown in panel b) and those for the impact on consumption are shown in panel c). Derived estimates are shown in panel d).

\section{Table 5 here}

\section{Determinants of Bribe Payment}

With a ten percent increase in participation in the Gram Sabha meetings, bribes paid by the household declines by $0.38 \%$. Second, regime change from a male to a female Pradhan reduces bribes by $11.2 \%$, while a change in the opposite direction has no impact. Deininger et al (2012 a, b) have shown that women Pradhans on an average are able to improve the process of governance. Since bribes are paid for all types of reasons (Table 2) our result is consistent with female Pradhans improving targeting, problem solving and reducing misconduct. We also note that participation in Gram Sabha Meetings and the election of a female Pradhan both reduce bribes.

The results on the impact of reelection of the Pradhan are not strong, but are consistent with such reelection leading to reduced payments of bribes. It does not appear that the consolidation of power from reelection leads to more bribes being extracted. But we may be faced with simultaneity here: A Pradhan who accepts fewer bribes may be more likely to be reelected.

How does outside political support affect the payment of bribes? Even though the 73rd amendment does not clearly state that the pradhan or the ward members shall not associate himself/herself with any political party, orders issued by various state governments are clear. Orissa for example in its order states "There is a complete ban on political parties and elections should be held on a non-party basis”. Since the Panchayats receive a significant part of their finances from the State governments, this ban is ostensibly to minimize discrimination at the time of financial allocations to the various Panchayats that might arise due to political affiliations of the Pradhan. Observations during the survey suggest that such affiliations are not revealed by the candidates at the time of elections (to avoid detection by 
election monitors). ${ }^{5}$ However such party affiliations may be known or they may be announced by the winner post elections. The winner may then favor party sympathizers or members in the allocation of benefits from programs. Other households will have to engage in various second best strategies to gain access to these resources. Consistent with this hypothesis, we find that an increase in the incidence of support from political parties leads to a $13 \%$ increase in the payment of bribes.

An increase in the bribe concentration index (the share of the bribes paid directly to elected leaders) in a village leads to increased payments of bribes. If the bribe concentration index was to go up by 10 percent, e.g. from 7 percent to 17 percent, then per capita bribes would go up by 3.5 percent. In villages in which there is a broad bribe network rather than bribe collection by powerful elected officials, less bribes are paid. Since the bribe concentration index can go up because the Pradhan is more powerful, or because he/she is more directly approachable by the villagers for problem resolution, more bribes appear to be associated with either of these changes.

The Indices of autonomy over expenditures come from state level schedules that provided the information on whether the specific function is performed by the Panchayat or not for different programs which are implemented at the village level. Out of these we selected the 16 most important ones. Each Autonomy Index measures the proportion of the sixteen programs for which the specific function was devolved. If more powers over allocation of funds in programs and over the execution of programs are devolved to the Panchayats, bribe payment goes down, perhaps because such devolution leads to intensified participation and scrutiny of the programs by the village population. The coefficients are large and highly statistically significant. Increasing the autonomy over expenditures or over implementation by 10 percent will decrease bribe payment by 3.7 and 7 percent respectively. On the other hand, increasing the power of selecting beneficiaries by 10 percent will increase bribe payments by 7.5 percent. If all three measures of autonomy were to be increased by 10 percent, the amount of bribes would fall by 3.2 percent, it therefore matters how autonomy is increased.

To understand we return to the MGNREGS example from three states cited earlier. What was found was that the information about the receipt of financial allocations for this program was

\footnotetext{
${ }^{5}$ There are a few exceptions to this behavior. In the sates of West Bengal and Kerala even at the time of such elections the presence of the Communist party cadres was apparent. In a few cases in Tamil Nadu and Maharashtra there was overt exhibition of association with the regional political outfits.
} 
usually available only with the elected representatives of Panchayats. This created information asymmetry within the village because Pradhan and ward members then may have used this private information about the magnitude of this transfer to grant benefits (in the form of work allocations) to members of their own Jati. To other members of the village the work allocations could then have been "rationed out” against bribes.

In order to reduce the pathology of bribe payments associated with devolution of the selection of beneficiaries to the Panchayat, it would be important to increase the transparency over receipt of resources for the programs and the selection of beneficiaries. A first measure could be to widely publish in the village all the resources received. Once an electronic payment system is in place, the system could also be used to disseminate such information, or an audit committee of the Gram Sabha could be set up whose terms of references include such information dissemination. Second, the power to select beneficiaries could be transferred to the Gram Sabha, or a subcommittee of the Gram Sabha that reports to the Gram Sabha.

\section{i) Change in Participation in welfare programs}

A 10 percent increase in bribes leads to a 10.5 percent increase in the probability of program participation; i.e. the impact of bribes on change in participation is elastic. In panel $\mathrm{d}$ of Table 5 we show the resulting predicted program participation for households paying bribes and those not paying bribes, and see that the former are expected to participate almost three times as much as the latter, a huge increase.

We have already seen that regime change in favor of women reduced bribe payments significantly._We find that political reservations of the Pradhan position for women led to a substantial gain in program participation of almost 30 percent. But it appears to be more than wiped out in the subsequent Panchayat when the reservation ends. However to fully assess the impacts of reservations we have to take account of the interaction effect of reservations with the payments of bribes. The first derivatives of program participation with respect to reservations that take account of both the linear and the interaction terms are computed in panel d) of Table 5. Here we see that current participation has a first derivative at 0.71 while the past reservation has one of 0.7 , and both are statistically significant. There is therefore a legacy effect of the reservation of the Pradhan position in terms of average program participation, but it is much smaller than the current impact. This is consistent with the persistence of reservation effects in Deininger et al (2012 a, b) wherein it was shown that 
improved quality of governance as consequence of reservation will persist beyond the period of reservations. But in the case of program participation the persistence is not very large.

Growth in Panchayat expenditures Bribes: If bribes are required to get access to welfare programs, then an increase in such programs in a village could increase participation by households in such programs even in the absence of bribes as illustrated in the positive elasticity of program participation with respect to total village programs available. We include interaction terms between three types of program expenditures and the payments of bribes that measure the advantage gained by those paying bribes. The advantage gained by the bribe givers over others in the context of welfare programs is $45.8 \%$. We find that the impact of a growth in public goods combined with bribe payments is almost of the same magnitude. Perhaps the payment of bribes for public goods and for welfare programs involves the same networks or officials and therefore has complementary impacts. However, payment of bribes provides no advantage in the context of the growth of agricultural programs.

Autonomy over expenditures in these programs into the regressions did not have any explanatory power in the equation for access to welfare programs.

Poverty Status and Bribes: We find that being poor in either 1999 or 2006 and paying bribes sharply increased the elasticity of program participation relative to the left out category of non-poor households. If the system discriminates against the poor then bribes are a tool to overcome such discrimination.

\section{ii) Change in Consumption}

The direct impacts of paying bribes on consumption are highly significant. A ten percent increase in bribes leads to a 0.24 percent increase in consumption. Per capita bribes are slightly more than 30 Rupees per year while per capita consumption is about Rs 6500 . Therefore a 3 rupees increase in bribes is estimated to lead to an increase in per capita consumption of 156 rupees. The benefit-cost ratio of the bribe in terms of consumption is 52 , assuming no persistence of the benefit stream at all. By contrast, a ten percent increase in predicted total wealth increases consumption by 0.29 percent, just a small fraction more than a ten percent increase in bribes. But ten percent of total wealth on average is about 45 Rupees per capita, while ten percent of bribes are only 3 Rupees. These extremely high payoffs to paying bribes explain why they are increasing steadily. 
In contrast, participation in Gram Sabha meetings yields much lower consumption benefits to households as can be seen by the small magnitude of the coefficient (0.0004). If the average number of GS meetings attended is 2, increasing it to 3 while being an increase of 50 percent would increase private consumption by only about 1 Rupee. Gram Sabha participation is therefore not a good way to obtain private benefits, which is a desirable outcome.

Table 6 shows that the Affluent have by far the highest predicted consumption change at almost 21 percent on average, followed by the non-poor at 0.63 percent. The poor and ultrapoor have a predicted decline in consumption, with the average decline the sharpest for the ultra-poor at almost 9 percent. Payment of bribes also increases predicted growth for all consumption classes, with the largest proportional gain of 18.5 percent for the ultra-poor, followed by 9.8 percent for the poor. It is clear that the two poor groups cannot avoid paying bribes if they want their consumption to increase.

\section{Table 6 here}

The coefficients of Panchayat expenditures on agriculture, welfare programs and public goods on consumption are statistically significant but small. Average per capita expenditure was Rs 6500 in 2006, while per capita public expenditures on agriculture, welfare programs and public goods were Rs 75, 133 and 77 respectively. Combining these numbers with the eastocotoes of these expenditures on per capita consumption we calculate that a ten percent increase in Panchayat per capita expenditures on agriculture, welfare programs and public goods lead to average per capita consumption increases of Rs 3.25, 3.90, and 5.85 respectively. For the three types of expenditures only $43 \%, 29 \%$.and $45 \%$ of current expenditures are recovered in terms of an increase in per capita village consumption. But that may not be the whole story, if for example they generated savings and private investment, public investments, or spillovers into subsequent years. Or some of the expenditures could leak out of the village economy. A more comprehensive analysis will be needed to assess the full benefits of Panchayat public expenditures.

We also included the untied revenues from block grants and own taxes in the regression, but these show no impact on consumption, probably because any impact is already captured in by the expenditures on programs.

Household characteristics have predictable impacts on consumption: Average age and education of households, as well as the highest education achieved in the household are 
associated with increased consumption, while larger household size is associated with a decrease. All these effects are most likely to operate via increases in income.

\section{Conclusions and Policy Implications}

Given the poor state of supply of most public goods in rural areas of India a strategy to empower Panchayats to supply thee goods through elected officials was implemented through no less a policy measure than an amendment to the Constitution of India. Our analysis of household level data on bribes, however, does not leave us sanguine.

Average bribes paid increased between 1999 and 2006 and bribes are being used to address a broad range of problems. Repeated payments of bribes even by those who participate in programs have nearly doubled. Most of the bribes are paid not directly to elected officials but to persons understood to be connected to them or to other people with influence over programs. The number of people that have to be approached to resolve problems of any kind has increased. Of particular concern is that even the poorest households paid more bribes. What the research shows is that people pay bribes in order to have problems resolved, reduce malpractice and get access to welfare programs, and ultimately increase their consumption.

People resort to bribing since they are unable to have their problems resolved. Thus, the presence of bribes is an indication that the rural governance system is not transparent, inefficient, and that neither politicians nor service providers can be held properly to account by the citizens. Further, these problems are getting worse, rather than better.

Payments of bribes could be reduced by a large number of improvements in transparency, efficiency in program administration and accountability to citizens. Thus, we find that bribes decline with an increase of the household in Gram Sabha participation and through a regime change from male to female pradhan.

We showed that if a state grants more autonomy over program expenditures and over the execution of the programs to the Panchayats, bribe payments go down significantly, On the other hand devolving beneficiary selection to the Panchayats tends to increase bribe payments, almost offsetting the gains made via greater autonomy over expenditures and execution. Case studies suggest that information about receipt of resources for programs is closely held by elected and appointed village officials rather than disseminated, and that they also keep control over the beneficiary selection process and resolution of other problems. 
Devolving more powers to select beneficiaries to Panchayats therefore needs to be accompanied by improvements in transparency mechanisms over both resources available and beneficiary selection.

On the other hand, outside support by political parties in the elections tends to increase bribe payments. This may be because households not affiliated to the party of the winner may have to pay more bribes to have their problems resolved. Higher concentration of the bribe networks, with more bribes paid directly to the elected officials rather than an intermediary also tends to increase total bribe payments.

Households who pay bribes are able to increase their probability of participation in welfare programs almost three fold. Again political reservations for women tend to increase average program participation rates, with a small but significant legacy impact. An increase in programs available in the village increases participation rates on average. For welfare and public goods programs, also paying a bribe increases this impact by over 40 percent. We also show that the payment of bribes by people below the poverty line increases their probability of program participation sharply compared to the non-poor people (the left out category).

We also find that the impact of paying bribes on consumption per capita is very large. The affluent have by far the highest predicted consumption change followed by the non-poor. The poor and ultra-poor have a predicted decline in consumption, with the average decline the sharpest for the ultra-poor. Payment of bribes increases predicted growth for all consumption classes, with the largest proportional gain for the ultra-poor, followed by the poor. It is clear that the two poor groups cannot avoid paying bribes if they want their consumption to increase.

Whether bribes lead not just to private benefits, but also to social benefits depends on the purpose of the bribe. If it was paid to resolve a problem with the provision of a public good that benefits the entire or parts of a community, there could be positive spillovers to other households. However, if the bribe is paid to get access to a rationed welfare benefit, and leads to the exclusion of another household that does not pay a bribe, the consumption benefit of one household is wiped out by the consumption loss of another one, and there is no social benefit. Further research is required to sort these issues out.

Panchayat expenditures on agriculture, welfare programs and public goods on consumption are statistically significant but small. However, there could be spillovers to next year's 
consumption, to private savings or investment, and to generation of returns in terms of education and health, as well as the provision of public goods. Here too, further research is needed to estimate all of the benefits of Panchayat expenditures.

The purpose of this paper was to address the positive question of what determines the payment of bribes, and what impacts such payments have on private benefits of those who pay the bribes. For the individuals who pay bribes, they are a second-best response to these deep seated problems in rural governance that affect not only the Village Panchayats and higher levels of the Panchayat system, but also the sectors involved in rural public services and rural public goods.

\section{References}

Banerjee, A., Iyer, L. and R. Somanathan (2007), “Public Action for Public Goods” in Handbook of Development Econonomics, vol. 4, (T. Paul Schultze and John Strauss eds.) Amsterdam: North Holland.

Blakeslee, D. (2013), "Politics and Public Goods in Developing Countries: Evidence from India" Working Paper, Columbia University, Department of Economics.

Deininger, Klaus, A. Goyal, and H.K. Nagarajan (2012c), "Do changes in inheritance legislation improve women's access to physical and human capital: Evidence from India’s Hindu Succession Act.” NCAER-IDRC Working Paper No. 2

Deininger, Klaus, S. Jin, and H.K. Nagarajan. (2012b), "Can political reservations improve female empowerment? Evidence from local panchayat elections in rural India.” NCAER-IDRC Working Paper No. 1

Deininger, Klaus, H.K. Nagarajan and S. Paul (2012a), "Can political reservations empower women and affect economic outcomes? Evidence from rural India.” NCAER-IDRC Working Paper No. 4.

Desai, S., Dubey, A., Joshi, B., Sen, M., Sharif, A. and R. Vanneman (2011), Human Development in India: Challenges for a Society in Transition, New Delhi: Oxford University Press.

Foster, A. and M. Rosenzweig (2001), "Imperfect Commitment, Altruism, and the Family: Evidence from Transfer Behavior in Low-Income Rural Areas.” The Review of Economics and Statistics, 83(3), 389-407.

Foster, A. and M. Rosenzweig (2004), “Agricultural Productivity, Growth, Rural Economic Diversity and Economic Reforms: India, 1970-2000.” Economic Development and Cultural Change, 52(3), pp. 509-42.

Munshi, Kaivan and M. Rosenzweig (2008), “The Efficacy of Parochial Politics: Caste, Commitment, and Competence in Indian Local Governments.” Working Papers 964, Economic Growth Center, Yale University

Kapteyn, A. and D. Fiebig (1981), "When are two stage least squares and three stage least squares identical?” Economics Letters, 8(1), pp. 53-57. 
Table 1: Sample, village and household characteristics: 1999-2006\#

\begin{tabular}{|c|c|c|c|}
\hline Variables & $\begin{array}{l}2006 \\
\text { (Approximately the } \\
\text { Current Panchayat) }\end{array}$ & $\begin{array}{l}1999 \\
\text { (Approximately the } \\
\text { Previous Panchayat) }\end{array}$ & $\begin{array}{c}\% \\
\text { change }\end{array}$ \\
\hline \multicolumn{4}{|l|}{ Sample Characteristics } \\
\hline Number of states & 17 & 17 & 0 \\
\hline Number of Districts & 104 & 104 & 0 \\
\hline Number of Blocks & 163 & 163 & 0 \\
\hline Number of villages & 241 & 241 & 0 \\
\hline Number of households in the panel & 5,885 & 5,885 & 0 \\
\hline Average number households in all villages & 700.50 & 622.9 & 12.46 \\
\hline \multicolumn{4}{|l|}{ Household Characteristics } \\
\hline Household Size & 5.24 & 6.23 & -15.89 \\
\hline Age of head & 51.16 & 49.42 & 3.52 \\
\hline Years of Schooling of HH Head & 5.11 & 4.46 & 14.57 \\
\hline$\%$ of male children ( $<15$ years) & 0.81 & 0.61 & 32.48 \\
\hline$\%$ of female children (<15 years) & 0.70 & 0.53 & 30.70 \\
\hline Per capita consumption (Rs) & 6568.28 & 5857.37 & 12.14 \\
\hline Per capita wealth & 159521.1 & 110230.3 & 44.72 \\
\hline Poverty (Head Count) & 24.98 & 30.60 & -18.37 \\
\hline Ultra-Poor & 3.41 & 1.5 & 127.33 \\
\hline Poor & 21.57 & 29.1 & -25.88 \\
\hline Non-Poor & 52.45 & 50.9 & 3.05 \\
\hline Affluent & 22.57 & 18.5 & 22.00 \\
\hline Inherited wealth & 708874.5 & 559465.3 & 26.71 \\
\hline Number of village shocks & 1.19 & 1.23 & -3.25 \\
\hline Number of household shocks & 1.14 & 1.02 & 11.76 \\
\hline Average Value of bribes (Rs.) per household & 167.33 & 120.33 & 39.06 \\
\hline Bribe concentration index & 0.07 & 0.04 & 75.00 \\
\hline \multicolumn{4}{|l|}{ Village Characteristics } \\
\hline Panchayat agriculture Expenditure (Per capita) & 74.64 & 145.22 & -48.60 \\
\hline $\begin{array}{l}\text { Panchayat expenditures on welfare programs } \\
\text { (Per capita) }\end{array}$ & 132.88 & 74.86 & 77.50 \\
\hline Panchayat public goods expenditure (Per capita) & 77.11 & 76.74 & 0.48 \\
\hline Panchayat untied resources (Per capita) & 122.03 & 93.61 & 30.36 \\
\hline Regime change (Female to male) & 22.75 & 17.17 & 32.50 \\
\hline Regime change (Male to female) & 26.18 & 22.32 & 17.29 \\
\hline Re-election of Pradhan & 19.74 & 13.73 & 43.77 \\
\hline Outside support from political party & 83.26 & 77.68 & 7.18 \\
\hline$\%$ villages reserved for women & 30.47 & 26.18 & 16.39 \\
\hline $\begin{array}{l}\text { Average number of centrally sponsored schemes active } \\
\text { in villages }\end{array}$ & 14.13 & 12.31 & 14.78 \\
\hline $\begin{array}{l}\text { Proportion of adults that attend at least one GS } \\
\text { meeting }\end{array}$ & 88.28 & 75.69 & 16.63 \\
\hline Number of GS meetings held & 13.33 & 7.10 & 87.75 \\
\hline \multicolumn{4}{|l|}{ Fiscal systems characteristics } \\
\hline Index of Autonomy over expenditures & 0.56 & - & - \\
\hline Index of Autonomy in selecting beneficiaries & 0.78 & - & - \\
\hline Index of Autonomy in execution & 0.77 & - & - \\
\hline
\end{tabular}

\#For precise definitions of variables see Annex table 3 
Table 2: Factors Affecting Payment of Bribes*

\begin{tabular}{|c|c|c|c|c|c|c|}
\hline \multirow[b]{2}{*}{ Variables } & \multicolumn{3}{|c|}{ Current Panchayat Period (2006) } & \multicolumn{3}{|c|}{ Previous Panchayat Period (1999) } \\
\hline & $\begin{array}{l}\text { Proportion } \\
\text { of } \\
\text { households } \\
\text { affected }\end{array}$ & $\begin{array}{l}\text { Proportion of } \\
\text { households } \\
\text { that paid } \\
\text { bribe }\end{array}$ & $\begin{array}{l}\text { Average } \\
\text { number of } \\
\text { functionaries } \\
\text { approached }\end{array}$ & $\begin{array}{l}\text { Proportion } \\
\text { of } \\
\text { households } \\
\text { affected }\end{array}$ & $\begin{array}{l}\text { Proportion } \\
\text { of } \\
\text { households } \\
\text { that paid } \\
\text { bribe }\end{array}$ & $\begin{array}{l}\text { Average } \\
\text { number of } \\
\text { functionaries } \\
\text { approached }\end{array}$ \\
\hline \multicolumn{7}{|c|}{ Pertaining to the community } \\
\hline Water ${ }^{\#}$ & 0.777 & 0.82 & $2.32(0,18)$ & 0.780 & 0.80 & $1.56(0,12)$ \\
\hline Health & 0.539 & 0.609 & $3(0,16)$ & 0.533 & 0.586 & $1.64(0,11)$ \\
\hline Road & 0.758 & 0.807 & $2.23(0,14)$ & 0.741 & 0.766 & $1.41(0,11)$ \\
\hline Education & 0.376 & 0.441 & $2.15(0,18)$ & 0.363 & 0.420 & $1.47(0,9)$ \\
\hline Street Light & 0.672 & 0.667 & $2.12(0,12)$ & 0.638 & 0.638 & $1.42(0,10)$ \\
\hline Sanitation & 0.653 & 0.680 & $2.15(0,17)$ & 0.632 & 0.634 & $1.32(0,11)$ \\
\hline Others & 0.489 & 0.518 & $2.14(0,10)$ & 0.475 & 0.488 & $1.37(0,10)$ \\
\hline \multicolumn{7}{|c|}{ Household Specific } \\
\hline $\begin{array}{l}\text { Public Work } \\
\text { Program }\end{array}$ & 0.721 & 0.795 & $2.242(0,19)$ & 0.685 & 0.781 & $1.54(0,11)$ \\
\hline Education & 0.182 & 0.213 & $2.261(0,15)$ & 0.163 & 0.190 & $1.42(0,10)$ \\
\hline Health & 0.145 & 0.154 & $3(0,12)$ & 0.143 & 0.155 & $1.55(0,10)$ \\
\hline Other & 0.200 & 0.234 & $2.15(0,15)$ & 0.223 & 0.234 & $1.348(0,9)$ \\
\hline \multicolumn{7}{|c|}{ Reduce expected mal practices (household level) } \\
\hline $\begin{array}{l}\text { Beneficiary } \\
\text { selection }\end{array}$ & 0.480 & 0.524 & $2.09(0,14)$ & 0.462 & 0.495 & $1.43(0,11)$ \\
\hline $\begin{array}{l}\text { Mid day meal } \\
\text { scheme }\end{array}$ & 0.214 & 0.250 & $3(0,11)$ & 0.175 & 0.188 & $1.81(0,10)$ \\
\hline $\begin{array}{l}\text { Functioning of } \\
\text { ration shop }\end{array}$ & 0.279 & 0.298 & $2.17(0,16)$ & 0.280 & 0.289 & $1.28(0,9)$ \\
\hline $\begin{array}{l}\text { Ration card } \\
\text { distribution }\end{array}$ & 0.440 & 0.497 & $2.22(0,17)$ & 0.425 & 0.487 & $1.47(0,10)$ \\
\hline Observations & 5885 & 3501 & - & 5885 & 3005 & - \\
\hline
\end{tabular}


Table 3: Payment of Bribes and Access to Functionaries

\begin{tabular}{lcccc}
\hline Variables & \multicolumn{2}{c}{ Current Panchayat Period } & \multicolumn{2}{c}{ Previous Panchayat Period } \\
\hline Consumption classes & $\begin{array}{l}\text { Proportion of } \\
\text { households that } \\
\text { paid bribes }\end{array}$ & $\begin{array}{l}\text { Average number } \\
\text { of functionaries } \\
\text { approached }\end{array}$ & $\begin{array}{l}\text { Proportion of } \\
\text { households that } \\
\text { paid bribes }\end{array}$ & $\begin{array}{l}\text { Average number of } \\
\text { functionaries } \\
\text { approached }\end{array}$ \\
\hline Poorest (Bottom one-third) & 0.337 & $2(0,13)$ & 0.298 & $1.558(0,15)$ \\
Medium (Middle one-third) & 0.332 & $2.317(0,18)$ & 0.261 & $1.465(0,11)$ \\
High (Upper one-third) & 0.329 & $2.174(0,17)$ & 0.275 & $1.315(0,11)$ \\
Observations & 3501 & - & 3005 & - \\
\hline
\end{tabular}

Table 4: Percentage of participation and bribe

\begin{tabular}{|c|c|c|}
\hline \multicolumn{3}{|c|}{ Participation in welfare program and bribe } \\
\hline Variables & $\begin{array}{c}\text { Current } \\
\text { Panchayat Period }\end{array}$ & $\begin{array}{c}\text { Previous } \\
\text { Panchayat Period }\end{array}$ \\
\hline Total Households & 5885 & 5885 \\
\hline Number of villages in the sample & 241 & 241 \\
\hline \multicolumn{3}{|l|}{ Bribe } \\
\hline Not paid bribe & 48.11 & 58.47 \\
\hline Paid bribe & 51.89 & 41.53 \\
\hline Paid bribes to persons with perceived links to functionaries ${ }^{*}$ & 97.91 & 97.73 \\
\hline Paid Bribes directly to the Functionary\# & 2.29 & 2.07 \\
\hline \multicolumn{3}{|l|}{ Bribe \& Participation } \\
\hline Participated in welfare program and paid Bribe ${ }^{\wedge}$ & 49.38 & 38.32 \\
\hline Average number of program participated in & 1.92 & 1.49 \\
\hline Participated in welfare program and not paid bribe & 46.17 & 55.77 \\
\hline Not Participated in welfare program and paid Bribe & 2.28 & 3.01 \\
\hline Not Participated in welfare program and not paid Bribe & 2.17 & 2.90 \\
\hline First time participants and paid bribe & 4.34 & 7.27 \\
\hline Repeat participants and paid bribe & 32.03 & 16.92 \\
\hline
\end{tabular}


Table 5: Change in participation in welfare program with payments of bribes

\begin{tabular}{|c|c|c|}
\hline Variables & Coefficient & Std. Err. \\
\hline \multicolumn{3}{|l|}{ a) Change in payment of log of bribes } \\
\hline Participated in GS meeting (change in log of number) & $-0.038^{\star \star}$ & 0.02 \\
\hline Regime Change (Male to female) & $-0.112^{\star}$ & 0.06 \\
\hline Regime Change (Female to male) & 0.059 & 0.048 \\
\hline Pradhan reelected in current panchayat & -0.064 & 0.078 \\
\hline Pradhan reelected in previous panchayat & $-0.146^{\star}$ & 0.086 \\
\hline Supported from political party & $0.130^{\star *}$ & 0.065 \\
\hline Bribe concentration index & $0.3498^{\star \star \star}$ & 0.135 \\
\hline Index of Autonomy over expenditures & $-0.372^{\star \star \star}$ & 0.148 \\
\hline Index of Autonomy in selecting beneficiaries & $0.743^{\star \star *}$ & 0.231 \\
\hline Index of Autonomy in execution & $-0.700^{\star \star \star}$ & 0.178 \\
\hline Constant & $0.876^{\star \star *}$ & 0.095 \\
\hline Chi2 & \multicolumn{2}{|c|}{$45.39 \star \star \star$} \\
\hline \multicolumn{3}{|l|}{ b) Change in in log of participation in welfare programs } \\
\hline Predicted change in payment of bribes (log) & $1.045^{\star \star \star}$ & 0.143 \\
\hline Political Reservation for women-current panchayat & $0.298^{\star \star}$ & 0.126 \\
\hline Political reservation for women-previous panchayat & $-0.595^{\star \star \star}$ & 0.185 \\
\hline Political reservation-current panchayat ${ }^{\star}$ Payment of bribes & $0.159^{\star \star *}$ & 0.037 \\
\hline Political reservation-previous panchayat ${ }^{\star}$ Payment of bribes & $0.329^{\star \star *}$ & 0.089 \\
\hline Growth in number of village programs (log) & $0.004^{\star * *}$ & 0.001 \\
\hline Panchayat expenditure on agricultural program Payment of bribes & 0.138 & 0.318 \\
\hline Panchayat expenditures on public goods* Payment of bribes & $0.446^{\star \star \star}$ & 0.186 \\
\hline Panchayat expenditures on welfare program* Payment of bribes & $0.458^{\star \star \star}$ & 0.159 \\
\hline Below poverty line $(2006)^{\star}$ Payment of bribes & $1.209^{\star \star \star}$ & 0.229 \\
\hline Below poverty line (1999)* Payment of bribes & $0.743^{\star \star \star}$ & 0.206 \\
\hline Constant & $-0.872^{\star \star \star}$ & 0.233 \\
\hline Chi2 & \multicolumn{2}{|c|}{$439.20 * * *$} \\
\hline \multicolumn{3}{|l|}{ c) Change in log of per capita consumption } \\
\hline Predicted change in payment of bribes (log) & $0.024^{\star \star \star}$ & 0.004 \\
\hline Predicted change in log of wealth & $0.029 * \star \star$ & 0.008 \\
\hline Change in log of number of GS meeting attended & $0.0004^{\star \star \star}$ & 0 \\
\hline Change in log of public expenditures on agricultural program & $0.005^{\star \star \star}$ & 0.001 \\
\hline Change in log of Panchayat expenditures on welfare programs & $0.008^{\star \star \star}$ & 0.001 \\
\hline Change in log of Panchayat expenditures on public goods & $0.009^{\star \star \star}$ & 0.002 \\
\hline Change in log of Panchayat untied resources & 0.002 & 0.002 \\
\hline Number of village level shocks between 1999 and 2006 & $-0.001^{\star * *}$ & 0 \\
\hline Change in log of number of household level shocks & 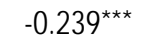 & 0.059 \\
\hline Change in log of average household age & $0.191^{\star * *}$ & 0.022 \\
\hline Change in log of household size & $-0.429^{\star \star \star}$ & 0.011 \\
\hline Change in log of highest years of education & $0.026^{\star \star *}$ & 0.008 \\
\hline Change in log of mean years of education of households & $0.116^{\star \star \star}$ & 0.01 \\
\hline Constant & $-0.038^{\star \star \star}$ & 0.011 \\
\hline Chi2 & \multicolumn{2}{|c|}{$1869.89^{\star \star \star}$} \\
\hline Hansen-Sargan over identification statistic & \multicolumn{2}{|c|}{$3215.29^{\star \star \star}$} \\
\hline \multicolumn{3}{|l|}{ d) Derived estimates } \\
\hline Predicted program participation if bribes are paid\# & \multicolumn{2}{|c|}{$1.57(73 \%)$} \\
\hline Predicted program participation if bribes are not paid"\# & \multicolumn{2}{|c|}{$0.57(27 \%)$} \\
\hline Predicted consumption growth if bribes paid\# & \multicolumn{2}{|c|}{0.11} \\
\hline Predicted consumption growth if bribes are not paid\# & \multicolumn{2}{|c|}{0.07} \\
\hline Impact of current reservation on participation\#\# & \multicolumn{2}{|c|}{$0.71^{\star \star \star}(\operatorname{chi} 2=32.18)$} \\
\hline Impact of previous reservation on participation\#\# & \multicolumn{2}{|c|}{$0.07^{\star \star \star}($ chi2 $=5.39)$} \\
\hline Number of observations & \multicolumn{2}{|c|}{5885} \\
\hline
\end{tabular}

\#As predicted by the systems of equations (Percentage contribution to total participation in parenthesis)

\#\# First derivative of participation with respect to reservations, using both linear and interaction term with bribe paid 
Table 6: Predicted Consumption growth with and without bribes

\begin{tabular}{|l|c|c|c|c|}
\hline \multicolumn{5}{|c|}{ Predicted consumption growth } \\
\hline $\begin{array}{l}\text { Household } \\
\text { groups }\end{array}$ & $\begin{array}{c}\text { Not } \\
\text { paid bribe }\end{array}$ & Paid bribe & Difference & All \\
\hline Ultra-poor & -0.103 & 0.082 & 0.185 & -0.088 \\
\hline Poor & -0.055 & 0.043 & 0.098 & -0.049 \\
\hline Non-poor & 0.061 & 0.094 & 0.033 & 0.063 \\
\hline Affluent & 0.207 & 0.255 & 0.048 & 0.209 \\
\hline Total & 0.071 & 0.112 & 0.041 & 0.073 \\
\hline
\end{tabular}


Table A1: Status of Public Goods Supply in Indian villages: 1991 and 2001

\begin{tabular}{|c|c|c|c|c|c|}
\hline Variables & 1991 & 2001 & Variables & 1991 & 2001 \\
\hline \multicolumn{3}{|l|}{ Drinking water } & \multicolumn{3}{|l|}{ Health Facilities } \\
\hline Any & 93 & 94 & Health Centre & 2 & 2 \\
\hline Tap & 21 & 41 & Primary & 5 & 7 \\
\hline Well & 68 & 62 & Health sub centre & 9 & 19 \\
\hline Hand pump & 58 & 75 & Maternity-child & 4 & 7 \\
\hline Tube well & 23 & 33 & Hospital & 3 & 5 \\
\hline River & 10 & 10 & Dispensary & 6 & 6 \\
\hline \multicolumn{3}{|c|}{ Commerce and Transport } & \multicolumn{3}{|l|}{ Irrigation } \\
\hline Post Office & 32 & 34 & Any & 38 & 46 \\
\hline Telegraph & 2 & 3 & Government Canal & 11 & 15 \\
\hline Phone & 11 & 44 & Private Canal & 1 & 1 \\
\hline Paved Road & 47 & 62 & Tank & 3 & 3 \\
\hline \multicolumn{3}{|l|}{ Electrification } & Tube well (electrified) & 6 & 8 \\
\hline Any & 74 & 78 & Tube well (non-electric) & 7 & 8 \\
\hline Domestic & 68 & 77 & Well (electrified) & 3 & 5 \\
\hline Agricultural & 57 & 64 & Well (non-electrified) & 2 & 2 \\
\hline Industrial & 37 & 56 & Uncultivated & 13 & 13 \\
\hline \multicolumn{6}{|l|}{ Education } \\
\hline Any & 78 & 81 & & & \\
\hline Primary School & 76 & 80 & & & \\
\hline Middle School & 25 & 33 & & & \\
\hline High School & 13 & 16 & & & \\
\hline Adult Literacy & 6 & 12 & & & \\
\hline
\end{tabular}

Source: Blakeslee (2013) based on Census of India, 1991 and 2001.

Figures represent percentage of villages in 449 out of 534 Lok Sabha constituencies, hence an overwhelmingly large part of the country. 


\section{Table A2: Estimation of Change in Wealth}

\begin{tabular}{|c|c|c|}
\hline Variables & Coef. & S.E.. \\
\hline \multicolumn{3}{|l|}{ Change in wealth } \\
\hline Age of household head in 1999 & $-0.007 * * *$ & 0.002 \\
\hline Change in mean of households' education & 0.073 & 0.049 \\
\hline Change in variance of households' education & $0.045^{* *}$ & 0.023 \\
\hline Change in maximum of households' education & 0.082 & 0.059 \\
\hline Number of male child in 1999 ( $<15$ years) & 0.033 & 0.047 \\
\hline Number of female child in 1999 (<15 years) & $-0.114^{* * *}$ & 0.045 \\
\hline Number of male child in 2006 ( $<15$ years) & $0.062 * * *$ & 0.023 \\
\hline Number of female child in 2006 ( $<15$ years) & 0.033 & 0.023 \\
\hline Inherited wealth in 1999 & $-0.283 * * *$ & 0.008 \\
\hline Dummy for non-co-resident father of household head in 2006 & $0.410 * * *$ & 0.152 \\
\hline Dummy for non-co-resident brother of household head in 2006 & $0.351 * * *$ & 0.109 \\
\hline Dummy for non-co-resident sister of household head in 2006 & $-0.376 * * *$ & 0.194 \\
\hline Dummy for non-co-resident father of household head in 1999 & -0.222 & 0.143 \\
\hline Dummy for non-co-resident brother of household head in 1999 & $-0.532^{* * *}$ & 0.100 \\
\hline Dummy for non-co-resident sister of household head in 1999 & $-0.304 * *$ & 0.154 \\
\hline Constant & $-0.007 * * *$ & 0.002 \\
\hline Chi2 & \multicolumn{2}{|c|}{$1564.63^{* * *}$} \\
\hline Number of Observations & \multicolumn{2}{|c|}{5885} \\
\hline
\end{tabular}




\section{Annex Table 3: Definition of variables}

\begin{tabular}{|c|c|}
\hline Variables & Definition \\
\hline $\begin{array}{l}\text { Public } \\
\text { expenditures on } \\
\text { Agricultural } \\
\text { programs }\end{array}$ & $\begin{array}{l}\text { All agricultural programs that comes to the village. These include expenditures } \\
\text { on irrigation, electrification, credit \& input subsidies, and watershed } \\
\text { development programs under DRAP and DDP etc. }\end{array}$ \\
\hline $\begin{array}{l}\text { Public } \\
\text { expenditures on } \\
\text { Public goods }\end{array}$ & $\begin{array}{l}\text { All public good financing that comes to village. These include expenditures on } \\
\text { drinking water, sanitation \& sewage, roads \& transportation, schools \& } \\
\text { education, health facilities, Pradhan Mantri Grameen Sadak Yojana (PMGY) } \\
\text { etc. }\end{array}$ \\
\hline $\begin{array}{l}\text { Public expenses } \\
\text { on welfare } \\
\text { programs }\end{array}$ & $\begin{array}{l}\text { All public goods ton welfare programs. These include expenses on access to } \\
\text { local government schemes, employment schemes of food for work, social } \\
\text { issues \& ceremonies, Below Poverty Line (BPL) programs, Indira Awas } \\
\text { Yojana (IAY), Samagra Awas Yojana, Annapurna, Mid day meal etc }\end{array}$ \\
\hline $\begin{array}{l}\text { Village untied } \\
\text { resources }\end{array}$ & $\begin{array}{l}\text { All revenue from grants and own taxes. These include revenue from state } \\
\text { finance commission, land tax, water usage tax, stamp papers and other local } \\
\text { taxes }\end{array}$ \\
\hline Ultra-Poor & Per capita exp. is less than $1 / 2$ of poverty line \\
\hline Poor & Per capita exp. is greater than $1 / 2$ of poverty line and less than poverty line \\
\hline Non-Poor & Per capita exp. is greater than poverty line and less than 2 times of poverty line \\
\hline Affluent & Per capita exp. is greater than 2 times of poverty line \\
\hline
\end{tabular}

